\title{
The Relationships among Social, Environmental, Economic CSR Practices and Digitalization in Polish Energy Companies
}

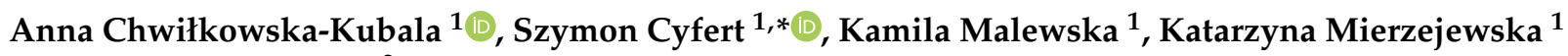 \\ and Witold Szumowski ${ }^{2}$ \\ 1 Department of Organization and Management Theory, Poznań University of Economics and Business, \\ al. Niepodległości 10, 61-875 Poznań, Poland; anna.chwilkowska-kubala@ue.poznan.pl (A.C.-K.); \\ kamila.malewska@ue.poznan.pl (K.M.); katarzyna.mierzejewska@ue.poznan.pl (K.M.) \\ 2 Department of Organization and Management Theory, Wrocław University of Economics and Business, \\ ul. Komandorska 118/120, 53-345 Wrocław, Poland; Witold.Szumowski@ue.wroc.pl \\ * Correspondence: s.cyfert@ue.poznan.pl
}

check for updates

Citation: Chwiłkowska-Kubala, A.; Cyfert, S.; Malewska, K.; Mierzejewska, K.; Szumowski, W. The Relationships among Social, Environmental, Economic CSR Practices and Digitalization in Polish Energy Companies. Energies 2021, 14, 7666. https://doi.org/10.3390/ en14227666

Academic Editor: Wen-Hsien Tsai

Received: 18 October 2021

Accepted: 10 November 2021

Published: 16 November 2021

Publisher's Note: MDPI stays neutral with regard to jurisdictional claims in published maps and institutional affiliations.

Copyright: (C) 2021 by the authors Licensee MDPI, Basel, Switzerland. This article is an open access article distributed under the terms and conditions of the Creative Commons Attribution (CC BY) license (https:// creativecommons.org/licenses/by/ $4.0 /)$.

\begin{abstract}
This paper explores relationships among CSR practices in the social, economic and environmental dimensions and digitization in the Polish energy companies. The study used the CATI method, and the data obtained from 110 companies was analyzed using a set of methods starting with correlation analysis, through regression analysis, including backward stepwise regression. Obtained results led to the formulation of SEM (Structural Equitation Modelling) model that has been tested. Results confirm the influence of social CSR practices on practices in economics and environmental CSR dimensions and on the level of digitalization. Research also suggests that there is essentially no significant impact of the size of the enterprise on the level of digitalization, as well as on any of the analyzed types of CSR practices.
\end{abstract}

Keywords: CSR; social practices; economic practices; environmental practices; digitalization; energy sector companies

\section{Introduction}

Corporate Social Responsibility (CSR) is one of the highly discussed concepts in management science [1-3], which is justified by the fact that organizations are under the pressure of various interest groups who expect the organization to be socially responsible [4]. The results of research conducted in the area of CSR suggest that implementing CSR assumptions, appreciating the importance of responsibility for the community and the environment $[5,6]$ provide the possibility of sustainable development of enterprises in various sectors [7-11].

Although the operational risk related to energy production, the size of enterprises in the sector, as well as the level of impact on the economy and the environment are factors prompting the inclusion of CSR assumptions in the activities of energy companies [12-17], the current state of research on the determinants of CSR implementation should be assessed as unsatisfactory. However, the research on the involvement of energy sector companies in CSR activities emphasizes the role and significance of exogenous and endogenous factors and describes CSR practices [13,18-26], but ignores the relationship between practices in CSR dimensions and the impact of these practices on digitalization. The adoption of these methods shows the complexity of CSR in the literature [27] and the holistic implementation of CSR [28,29], allowing the formulation of the research problem of the study to investigate how the relationship between individual CSR practices reinforces (or weaken) each other.

It is also interesting to know if there is a connection between individual practices and digitalization that will play a critical role in the development of energy sector enterprises. Although digital technologies have been used for decades to improve energy systems [30], 
and several studies have shown the close association of digital transformation with organizational efficiency, to date, very few researchers have explored links between the level of digitalization and CSR, as well as the relationships between these concepts.

Therefore, the aim of the article is to identify relationships among practices of particular dimensions of CSR, as well as to analyze the relationship between CSR practices and digitalization. The key contribution of the study is to highlight the role of social practices as key practices in energy sector companies, affecting both economic and environmental practices and digitalization.

The paper is structured as follows: in Section 2, we present the theoretical background, focusing on the concept of CSR and defining economic, environmental and social CSR practices. We also relate to the concept of digitalization, phases in the process of implementing digital transformation strategy in the energy sector enterprises and describe relations among CSR and digitalization. In Section 3, we discuss the empirical research conducted, showing the method of obtaining data and characterizing the research sample, the adopted variables, and the SEM models used. Sections 4 and 5 contains the results and the discussion of the results. The paper finishes with conclusions, research limitations and further research directions in Section 6.

\section{Theoretical Background}

\subsection{CSR Concept}

Considering the variety of methodologies adopted in studies on CSR [31], this paper adopts the optics of three categories of CSR practices: social, environmental, and economical. This approach can be observed in other current research on CSR [32-35].

\subsubsection{Social Practices}

The interest in implementing the CSR concept in enterprises due to benefits from developing the social aspect is growing every year $[36,37]$. The considerations of theoreticians and the experience of practitioners have convinced internal stakeholders to work more willingly and with greater engagement in companies where the development of competencies, motivation, work safety and work-family balance in these workplaces [38,39]. In addition, external stakeholders are more willing to cooperate with enterprises that work for the benefit of the local community and care for its well-being [40,41]. In their considerations, Husted and Salazar [42] argue that these actions should not be altruistic. In order to obtain tangible benefits for the company, management staff should act strategically. Strategic social investors gain good reputation and more qualified personnel. This creates added value and translates into higher profitability of the business. In other studies, Husted et al. $[43,44]$ prove that investing in social practices and creating social strategies in enterprises can contribute to increased value and competitive advantage. In turn, Bacinello et al. [45] suggest that any measures that promote employee well-being and motivation contribute to higher business results.

Social CSR practices refer to the impact that enterprises have on the social prosperity of the entire country and individual stakeholders. These are practices that go beyond the necessity to comply with the law to promote the social well-being [46]. Being socially responsible means being responsible for the social effects that companies have on people directly and indirectly [13]. Activities undertaken by enterprises as part of social practices can contribute to the achievement of sustainable development goals in the long run [11,21]. Globally, social issues are very worrying for developing countries [47], but care for them is also necessary for highly developed countries. The existence of enterprises depends to a large extent on the prosperity and well-being of the community in which they operate. Being aware of this, more and more organizations are actively involved in solving social problems and implementing solutions aimed at increasing social welfare $[13,48,49]$.

Literature studies conducted for the purposes of this study indicate the diversity of social practices implied in the research. Based on a review of the latest literature [13,38-41,50-56], the most commonly used social practices are: 
(1) assessment of the impact of activities undertaken by the enterprise on the local society,

(2) cooperation on social and charity projects,

(3) promotion of the development of the local community, protection of heritage,

(4) ensuring work-family balance of employees,

(5) ensuring a high level of work safety,

(6) care for the development of the employees' high competencies and care for the proper motivation of employees

(7) conducting open cooperation with stakeholders.

\subsubsection{Environmental Practices}

Pointing to the re-evaluation of the approach to environmental issues [57], an increase in the stringency of environmental protection regulations and a change in stakeholders' expectations regarding responsible behavior for the environment [58], the researchers note that enterprises use Corporate Social Responsibility strategies to mitigate the social and environmental effects of their own operations [59].

Mijatovic et al. [60] suggest that environmental practices aim to minimize environmental damage and promote environmental sustainability efforts across corporate boundaries. Similarly, environmental practices are defined by Gadenne et al. [57] assuming that these activities are undertaken by enterprises in order to reduce the impact of their activities on the environment. Uhlaner et al. [61] points out that environmental practices refer to activities that preserve and protect natural resources. Hoogendoorn et al. [62] suggest that environmental practices encompass those activities undertaken by companies that are not classified as entrepreneurial in the sense of capturing and exploiting market opportunities, which allows them to assume that environmental practices apply to any purposeful, environmentally friendly activity undertaken by a company.

Pointing to the rationale for implementing environmental practices, Tate et al. [63] suggest that companies implement voluntary environmental practices for two reasons: firstly, because they can build a competitive advantage through better access to and management of natural resources, and secondly, to maintain a positive reputation among stakeholders. Gadenne et al. [57] also relate to the impact of external and internal stakeholders on implementing environmental management practices. On the other hand, Babiak and Trendafilova [64] pay attention to the strategic motives of the environmental focus on CSR. Morales-Raya et al. [58] claim that companies implement environmental practices to meet the environmental expectations of users, achieve legality, and create and maintain environmentally friendly images. Hoogendoorn et al. [62] show that strict environmental regulations encourage companies to take activity to protect the environment, but only with ecological products and services.

Referring to the benefits from using social practices, Ahmed et al. prove that companies with higher levels of corporate social and environmental practices have a lower cost of equity capital [65]. The results of the research by Seles et al. suggest that environmental practices that are linked to corporate strategies and are characterized by dynamic capabilities, can improve business performance even during economic crisis [66]. The impact of environmental practices on improving business results is also shown by Graham and Potter [67], although the results of Chen and Ho [68] suggest that pro-environmental practices do not always increase sales, as it depends on the attitude of customers. Mijatovic et al. [60] suggest linking environmental practices with competitive advantage and reputation benefits.

The literature on the subject shows that environmental CSR practices include [61-63,66,69]:

(1) assessing the environmental impact of activities,

(2) introducing energy and water-saving activities,

(3) developing renewable energy sources,

(4) choosing environmentally friendly suppliers,

(5) encouraging clients to care for the natural environment, 
(6) implementing waste and pollution control systems,

(7) striving to reduce the environmental impact of energy production/transmission,

(8) creating activities that care for the natural environment.

\subsubsection{Economic Practices}

Although the research of Garay and Font suggests that the premises of implementing CSR in most enterprises are altruistic reasons [69], the literature often points to potential benefits related to shaping a competitive advantage and achieving higher economic results [70]. Moreover, the original assumptions of CSR allow us to consider the economic dimension as the basic one because, without economic results, it would not be possible to implement the practices in the other dimensions [71]. McCain et al. [72] suggest that CSR is aimed at strengthening the fairness and honesty of business practices, promoting product safety, protecting employees' welfare, and increasing a company's environmental performance.

Zhao et al. [73] show that the economic dimension of CSR relates to the extent to which firms fulfil their duties and obligations related to economic activity in order to sustain economic growth. Economic growth is the fundamental responsibility of any business organization, not only to shareholders but also to all employees. Therefore, while economic CSR practices are internally oriented, it benefits society. Practices implemented in the economic dimension refer to society's expectations that the enterprise will be profitable in the long term and will ensure stable employment, and that efficient and effective activity in the operational sphere will translate into the possibility of offering high-quality goods and services $[70,74]$. Mahmood and Bashir view economic practices similarly, pointing out that they refer to the fair distribution of scarce resources to produce goods and services [75]. Zhao et al. suggest that the practices undertaken in economic CSR create benefits for firms, but not directly for society [73]. Costa and Menichini, emphasizing that the economic dimension relates to the impact on stakeholders, suggest that it takes into account the indirect economic effects of the organization's activities [33]. While discussing CSR, Singh and Mittal point out that economic practices refer to organizational practices that are designed to prevent any kind of legal abuse and ensure compliance with the law [76]. Wut et al. [77] suggest that economic CSR practices encompass employment policies and provide direct and indirect employment. Torugs et al. assume that the economic dimension of proactive CSR regard with means by which companies try to prevent problems that may arise in their interactions with customers, suppliers and stakeholders in the market; it underlines the importance of a long-term management perspective related to the need to ensure sufficient cash flow for ensuring liquidity while ensuring sustained above-average return for shareholders [34].

Conducted analysis of research in the area of CSR economic practices [34,69,70,78-81] allowed to propose the following set of variables analyzed in the further course of the procedure:

(1) offering a competitive level of remuneration,

(2) treating customers and suppliers fairly,

(3) shaping good relations with responsible suppliers,

(4) providing high-quality products,

(5) carrying out cost-effective operations,

(6) investing in new technologies,

(7) providing a high level of reliability of energy supplies,

(8) managing financial risk.

\subsection{The Rationale for CSR Concept in Energy Sector Companies}

The issue of being socially responsible is discussed within the research on the energy sector [14-17] as one of those sectors that have substantial economic, environmental, and social impacts [82-84]. Several categories of the rationale for considering CSR commitment in energy sector companies may be mentioned-first of all, those which emerge from global trends on climate change [13], as well national politics on the social and economic 
influence of organizations. However, following CSR standards set by such organizations, such as, for instance, the United Nations, Organisation for Economic Cooperation and Development (OECD), etc., is a voluntary approach [20]. Within this group of considerations, one may note the substantial role of the historical context of a country. For instance, Garstecki et al. [85] point out that participating in politics of a multinational unions' organization (e.g., the European Union) enables to take advantage of financial sources, various CSR practices, as well as developing the awareness of the importance of CSR.

The second rationale considers formal standards related to meeting legal regulations of operating in a broad sense on the market (thus above mentioned social, environmental and economic influence of energy sector companies). In some cases, depending on a regulatory system, an organization is obliged to report its social and environmental impact [44]. This issue is also perceived as a motivator for enhancing a CSR pro-activity attitude of an energy company [24]; however, some research results suggest [23,24] that the regulatory system could clarify CSR practices.

The third rationale references the fact that CSR practices are focused on relationships with stakeholders [83]. In particular, Benyaminova et al. [26] and Karaman et al. [25] highlight the issue of shaping accurate CSR strategies, aiming at assuring stakeholders that a company performs an appropriate involvement in CSR activities. However, considering stakeholders' goals, Mory et al. [86], and Syrjälä and Takala [87] pay substantial attention to an internal group of stakeholders-employees.

The fourth rationale addresses societal aspects, with a view to the increasing societal expectations of what a company should be responsible for [13], therefore not considering the CSR aspects only from the point of view of particular stakeholders' goals, but the whole society as well [17]. However, de Vries et al. [88] argue that in some cases, CSR activities may be perceived as a way to achieve financial goals instead of real care of the natural environment or the society.

It is observed [26] that aiming at meeting stakeholders' expectations, the involvement in CSR activities can be exogenous in nature. A question arises, how much the CSR practices are rooted in a business philosophy - are they only a result of the conscious and real need to be responsible from the point of view of society? Considering an endogenous perspective, it is suggested [89-91] that a positive relationship exists between CSR and profitability. However, this relation may differ depending on adopted measures of 'performance' [92]. Nevertheless, according to McWilliams and Siegel [4] the effect of CSR practices on a company's financial performance is neutral.

Latapí et al. [18], based on a systematic review, feature a slightly different approach to the rationale for using the CSR concept in the energy sector companies. They suggest three determinants: internal drivers (related to such categories as business strategy, corporate culture, cost savings and profitability, environmental commitments and climate change mitigation and adaptation and risk prevention and management); external (including competitiveness, legislative and regulatory frameworks, social commitments and engagement, and stakeholder engagement and satisfaction); and connecting drivers (such as branding and reputation, reporting and disclosure, and social license to operate).

Referring briefly to the three dimensions of CSR (social, environmental and economic), one may note that the analysis of CSR reports of the energy sector carried out in 2007 by ECOTEC Research and Consulting Ltd. shows that the social dimension is most often neglected by enterprises in the energy industry. This state of affairs may be due to the fact that companies from the energy sector have a long history of reporting the economic and environmental effects of their activities. Moreover, social issues remain of secondary importance in the face of the ongoing debate on the climate threat [93], which is getting more intense every year [19]. The negligence in the social sphere of CSR in the energy sector companies is also indicated by studies conducted in the Baltic countries [20]. Among the main difficulties of CSR in the social dimension, the researchers mention insufficient cooperation with stakeholders, insufficient care for the competencies and motivation of employees, insufficiently functioning NGOs, the high price of energy 
compared to the low average income of the population, indebtedness of energy recipients, low public awareness of the activities of enterprises in the sector energy. The lack of information and awareness in society was considered the major barrier to the development of CSR in the energy sector. There is a lack of studies analyzing the broader scope and essence of social practices. However, taking into account the conclusions of the abovementioned studies [20], it seems reasonable for companies from the energy industry to assume the responsibility of imparting reliable knowledge, disseminating information on the transformation of the energy sector, and encouraging their clients to save energy and give advice on reducing greenhouse gases. In addition to addressing the CSR barrier, which is the lack of communication and integration between stakeholders [21], it is advisable to use new ICT and social media in the energy industry, which are considered the most effective tools for establishing and nurturing relationships with stakeholders on the basis of meaningful dialogue [22].

In turn, the study by Lee [91] suggests a positive impact of environmental responsibility on the financial performance of a company. This insight appears relevant with a view to the fact that the energy sector companies are classified as environmentally sensitive entities [25,94,95] as well as 'high impact' entities, from the environmental perspective [96]. Stjepcevic and Siksnelyte [13] highlight that the production and transmission of energy contribute in various manners to changes in the natural environment. The environmental responsibility is related not only to measuring the environmental impact and reducing pollution and emissions or minimizing use of fossil fuels, but also to raising awareness, reducing the environmental impacts of energy production and transfers, as well as promoting renewable sources development [13]. The environmental practices are those which can be linked directly to the topic of activities performed by energy sector companies. Lu et al. [96] paid attention to the fact that 'the main UN sustainable development goals linked to sustainable energy development targets (energy efficiency improvements, usage of renewable energy sources, and GHG emission reduction) and CSR principles set by Global Compact are based on environmental sustainability'.

The issue of economic practices in relation to the energy sector can be considered from various perspectives. As Stjepevic and Siksnelyte [13] point out, economic practices have been neglected, identifying them with the company's operations or financial results. While in the case of companies from the energy sector, particular attention should be paid to the assessment of the market demand in terms of economic development in which an energy company operates (or plans to operate). As Ionescu et al. [97] suggest, the energy sector from the global perspective contributes to a country's development (as well as to the development of other sectors within a given economy). Moreover, energy sector companies should also aim at meeting the goals of various stakeholders, including employees, customers, investors, financial institutions, and members of the management board.

\subsection{Digitalization of the Energy Sector}

The observed increase in the level of digitalization in enterprises from various sectors is a result of the progress in the processes of data analysis and connectivity, especially to the falling costs of data storage, a rapid process in advanced analytics (machine learning), or greater connectivity of people and devices as well as faster and cheaper data transmission $[30,98,99]$.

Digital technologies have been used to improve energy systems for decades. It should be emphasized that it was the energy sector that was the first recipient of large information technology systems [30]. Already in the 1970s, energy companies used information technologies to increase the efficiency of grid management and operation. Today, energy markets are monitored and controlled in real-time, covering vast geographic areas inhabited by a significant number of customers. The pace of the digitalization process in the energy sector is growing - in recent years, there has been a significant increase in investment in digital technologies undertaken by energy companies [30]. 
Digitalization of the energy sector is an important global trend with tangible benefits, such as access to a more efficient and reliable energy system. Digitalization is considered being a crucial tool and, at the same time, a prerequisite for ensuring the security of energy supply and flexibility, as well as the cost-effectiveness of solutions that will be used in the future [100]. It is a continuous process that involves all countries of the world. For this reason, this subject is more and more often undertaken by numerous researchers [101-109].

Digitalization of the energy companies focuses primarily on increasing the security and stability of the energy system. The main benefits of this process include the reduction of operating and maintenance costs, increased efficiency and stability, and the extension of life cycles of critical assets [110]. Digitalization and associated higher quality of data provide a more reliable basis for making investment decisions and enable the automation of a number of decision-making processes. Besides, it enables better satisfaction of customers' needs by integrating renewable energy sources and ensuring coordination between dispersed energy resources [100]. A more detailed analysis allows to identify three organizational aspects influenced by digital transformation: increase in customer experience and changing their life cycle (external aspect), changing business goals, leadership and organizational structure of the company (internal aspect), which ultimately translates into changes in its business model [111]. Some of the positive effects of digitalization on the electricity value chain are [112]:

1. in the production area: (a) optimization of the supply and management of fuel and spare parts, (b) preventive maintenance based on future market conditions;

2. in the area of trade: (a) improving the decision-making process through the use of big-data technology and risk-management models, (b);

3. in the area of energy transmission and distribution: (a) real-time remote monitoring to increase efficiency, (b) use of augmented reality tools to repair equipment in the field;

4. in the sales area: (a) creating new products and services corresponding to the real needs of customers, (b) the use of business platforms connecting significant numbers of customers and suppliers.

According to Dang and Vartiainen [113], three basic phases can be distinguished in the process of implementing digital transformation strategy in the energy sector enterprises: bootstrapping phase, acceleration phase and sustain phase. As part of bootstrapping phase, the management team organizes the business conditions necessary to carry out the digital transformation and prepares employees for the implementation of this change. Employees are aware of the need to digitize the company's operations. In the acceleration phase, the company uses modern information and communication technologies. In order to improve the production process, automation is introduced, and cooperation with new partners and research centers is established. The last phase of the implementation of the digital transformation strategy, which represents the highest level of digitalizationthe sustain phase-is characterized by the fact that the company's employees use and create new technological solutions. Digitalization took place not only at the organizational level but also at the individual level. It has become the foundation of the company's organizational culture.

The Smart Industry report prepared by Siemens and the Ministry of Entrepreneurship and Technology as well as the Digital Economy and Society Index of the European Commission shows that the Polish energy sector, despite the growing interest in the Industry 4.0 concept, still remains at the initial level of digitalization. Attention is drawn to the need to accelerate this process in order to increase the use of the commercial opportunities of digital technologies [114].

At present, the supply in the energy sector in Poland is characterized by a high degree of centralization. This is due to the fact that electricity is generated in large power plants and sent through transmission and distribution networks to passive end recipients [115]. It should be noted, however, that a significant part of the demand for electricity is inelastic in the short term due to the lack of change in energy consumption caused by price changes. It seems that the implementation of the assumptions of the Industry 4.0 concept, and in 
particular the acceleration of the digitalization process, may positively change the situation of the energy sector [116].

Summing up, it can be said that the Polish energy sector is at the initial stage of the digitalization process, and the level of robotization is one of the lowest in Europe. However, it should be emphasized that lowering the costs of digital technologies can definitely accelerate this process. The establishment of the Polish Industrial Platform 4.0, which is to be a kind of integrator of digital transformation, may also have a positive impact on this process.

\subsection{CSR Practices and Digitalization}

Forcadell et al. [117] indicate the growing importance of corporate sustainability and digitalization for companies, society, and decision-makers around the world, suggesting that by combining corporate sustainability and digitalization, mutually reinforces each other, giving better results than in isolation. In addition, Del Río Castro et al. provide evidence that the interplay of digitalization and sustainable development offers the potential to shape a greener economy and society, enabling the achievement of the SDGs [118]. Seele and Lock draw attention to the complex nature of the links between digitalization and sustainable development, pointing out that sustainable development adapts to the new opportunities and threats of the digital age, and that digitalization is a driving force that changes sustainable development [119]. Assuming the impact of CSR on digitalization, Latapí Agudelo et al. [120] emphasize the importance of including digitalization tools in CSR. Van der Velden and Maja also suggest that, thanks to sustainable development, digitalization, and its design can strengthen the organization's ability to respond to environmental phenomena [121].

Belyaeva and Lopatkova conclude that digitalization provides the necessary tools to ensure the development and integration of economic, social, and environmental aspects [122]. Brenner and Hartl also indicate the influence of digitalization on the perception of ecological and economic sustainability [32]. Seele and Lock suggest that digitalization can help increase environmental, social, and economic sustainability [119]. A similar observation is formulated by Bhutani and Paliwal, pointing out that digitalization can revolutionize socio-economic performance, creating a symbiotic relationship with inclusive growth and sustainable development [123]. Esposito and Ricci conclude that digitalization influences the approach to CSR disclosure [124]. The results of the Niehoff and Beier research also suggest that digitalization may positively affect the environmental dimension of sustainable development [125] Pointing to the tensions between sustainable development and digitalization, Arnold and Fischer [126] note that digital transformation requires a precise and fair foundation of value and added value in terms of sustainable development.

\section{Methods and Research Sample}

The Sample Selection and Description of the Research Tool

Firstly, in order to propose the variables of the survey, we conducted an in-depth literature review, which allowed us to propose a list of 23 variables that we assigned to three predefined basic CSR areas (described above). As Table 1 shows, ultimately, the following components of each type of CSR were supplied.

The above-mentioned practices were the basis for the development of a part of the research tool in the area of CSR.

Besides the measurement of activities in the area of CSR, it was necessary to determine the level of digitalization. Thus, the respondents were also asked to assess this level by pointing at one of the proposed phases in the process of implementing digital transformation strategy. The three-stage division of this process proposed by Dang and Vartiainen [113] (bootstrapping phase, acceleration phase and sustain phase) has been supplemented with an additional phase relating to the situation in which the management team is considering implementing a digital transformation strategy in the long term, but currently, this is not a strategic goal of the company. 
Table 1. Dimensions and CSR practices.

\begin{tabular}{|c|c|}
\hline Dimensions CSR & CSR Practices \\
\hline Economic practices & $\begin{array}{l}\text { - } \quad \text { offering a competitive level of remuneration, } \\
\text { - } \quad \text { treating customers and suppliers fairly, } \\
\text { - } \quad \text { phaping good relations with responsible suppliers, } \\
\text { - } \quad \text { carrying out cost-effective operations, } \\
\text { - } \quad \text { investing in new technologies, } \\
\text { - } \quad \text { providing a high level of reliability of energy } \\
\text { - } \quad \text { mapplies, } \\
\text { - }\end{array}$ \\
\hline Environmental practices & $\begin{array}{l}\text { - assessing the environmental impact of activities, } \\
\text { - } \quad \text { introducing energy and water-saving activities, } \\
\text { - } \text { developing renewable energy sources, } \\
\text { - encosing environmentally friendly suppliers, } \\
\text { environment, } \\
\text { - } \quad \text { implementing waste and pollution control systems, } \\
\text { - } \text { striving to reduce the environmental impact of } \\
\text { energy production/transmission, } \\
\text { creating activities that care for the natural } \\
\text { environment. }\end{array}$ \\
\hline Social practices & $\begin{array}{l}\text { - evaluation of the impact of undertaken activities on } \\
\text { the local society, } \\
\text { - } \quad \text { pooperation on social and charity projects, } \\
\text { comotion of the development of the local } \\
\text { - ensuring employees work and family life balance, } \\
\text { - ensuring work safety, } \\
\text { - employees' competency development and } \\
\text { - } \quad \text { motivation of employees, } \\
\text { open interaction with stakeholders. }\end{array}$ \\
\hline
\end{tabular}

Source: Own work.

Through a professional research company (DRB Polonia) direct interviews were conducted on the group of 110 managers working in different companies of the energy sector. A structured questionnaire was used to collect primary data.

There were a few factors that had an impact on performed survey. First of all, it resulted from the assumed research goal, which required quantitative research, indicating the links among the CSR activities, its basic areas, and digitalization level. Secondly, in order to check the communicativeness of the questionnaire (included in Appendix A), a pilot study among 30 respondents was carried out. The results of the pilot survey did not affect the modification of the list of areas or activities in the CSR field, but only some aspects of question formulation (understandable for the respondents) and allowed to propose scales we used-perception measures on a seven-stage Likert scale from 1 (strongly disagreeing) to 7 (strongly agreeing), which allowed for greater diversification of the respondents' answers.

In the next step, using the computer-assisted web interview (CAWI) method, we asked respondents to make an assessment of the CSR activities of their organizations. In the research proceedings, assuming the company as an analytical unit, the single respondent project was used. Table 2 presents the characteristics of the surveyed enterprises. 
Table 2. Characteristics of the surveyed enterprises $(n=110)$.

\begin{tabular}{ccc}
\hline & Organization's Age & \\
$0-5$ years & & $4.55 \%$ \\
$6-10$ years & & $24.55 \%$ \\
$11-25$ years & & $45.45 \%$ \\
more than 30 years & Number of Employees & $25.45 \%$ \\
& & $50.00 \%$ \\
$10-49$ & & $24.55 \%$ \\
$50-249$ & $25.45 \%$ \\
\hline
\end{tabular}

Source: own study.

\section{Research Results}

In order to determine the relationship among particular categories of CSR and to determine their impact on the level of digitalization, synthetic indicators for individual types of CSR activities were created, based on the arithmetic mean of individual components within the category. For each of the indicators, the test reliability coefficient values were calculated.

The alpha values of the indicators used for the purpose of the conducted analyses are presented in Table 3.

Table 3. Values of the Alfa Cronbach test reliability coefficient for individual indicators.

\begin{tabular}{cc}
\hline Indicator & Alpha Value \\
CSR economic practices & 0.899 \\
CSR environmental practices & 0.937 \\
CSR social practices & 0.875 \\
\hline Source: own study.
\end{tabular}

Presented values of an Alpha Cronbach test show the high-reliability internal consistency of a composite score.

In the next step of the proceedings, we have used a correlation and multiple regression analysis to determine (first) relation between each variable, and (secondly) the impact of each type of CSR on the level of digitalization. Correlation analysis (see Table 4), indicates the existence of high interdependence between indicators related to each type of CSR. This analysis also indicates the existence of interdependence between types of CSR activities and digitalization levels. This interdependence is highest in case of social practices (0.32) and lowest (but still statistically significant) in case of environmental practices.

Table 4. Correlation analysis results.

\begin{tabular}{ccccc}
\hline Variable & Digitalization & $\begin{array}{c}\text { CSR } \\
\text { Environmental } \\
\text { Practices }\end{array}$ & $\begin{array}{c}\text { CSR } \\
\text { Social } \\
\text { Practices }\end{array}$ & $\begin{array}{c}\text { CSR } \\
\text { Economic } \\
\text { Practices }\end{array}$ \\
\hline Digitalization & 1.000 & $0.256^{* *}$ & $0.319^{* *}$ & $0.307^{* *}$ \\
\hline CSR environmental practices & $0.256^{* *}$ & 1.000 & $0.629^{* *}$ & $0.573^{* *}$ \\
\hline CSR social practices & $0.319^{* *}$ & $0.629^{* *}$ & 1.000 & $0.739^{* *}$ \\
\hline CSR economics practices & $0.307^{* *}$ & $0.573^{* *}$ & $0.739^{* *}$ & 1.000 \\
\hline$*$ value $<0.05000$. Source: own study. & & &
\end{tabular}

In contrast, multiple regression analysis showed no statistically significant relationship between the different types of CSR activities and the level of digitalization (see Table 5). 
Table 5. Regression of the dependent variable-digitalization in relation to types of CSR.

\begin{tabular}{cccc}
\hline & & $\mathbf{R}^{\mathbf{2}} \mathbf{0 . 1 1 6}$ \\
\cline { 2 - 4 } & $\boldsymbol{\beta}$ & $\mathbf{t}$-Statistic & $\boldsymbol{p}$ \\
\hline CSR environmental practices & 0.066 & 0.049 & 0.581 \\
\hline CSR social practices & 0.173 & 0.154 & 0.239 \\
\hline CSR economic practices & 0.141 & 0.135 & 0.310 \\
\hline
\end{tabular}

Source: Own study.

As a result of this analysis (Table 6), one of the three CSR variables remained-social practices that influenced the level of digitalization.

Table 6. Result of backward stepwise regression of the dependent variable-digitalization in relation to types of CSR.

\begin{tabular}{cccc}
\hline & & $\mathbf{R}^{\mathbf{2}}=\mathbf{0 . 1 0 2}$ \\
\cline { 2 - 4 } & $\boldsymbol{\beta}$ & $\mathbf{t}-$ Statistic & $p$ \\
\hline CSR social practices & 0.319 & 3.504 & 0.001 \\
\hline Source: Own study & & &
\end{tabular}
Source: Own study.

The statistically significant impact of social practices on the level of digitalization, with the simultaneous interdependence between individual types of CSR, allowed for the formulation of a path model proposal aimed at explaining these relationships.

Bearing in mind that organizational maturity depends on the size of the organization [127], we took into account an additional variable in the model, which is the number of employees.

The proposed model (see Figure 1) assumed the influence of CSR social practices on digitalization and economic and environmental practices as well, and additionally influenced the size of the organization on each of the variables.

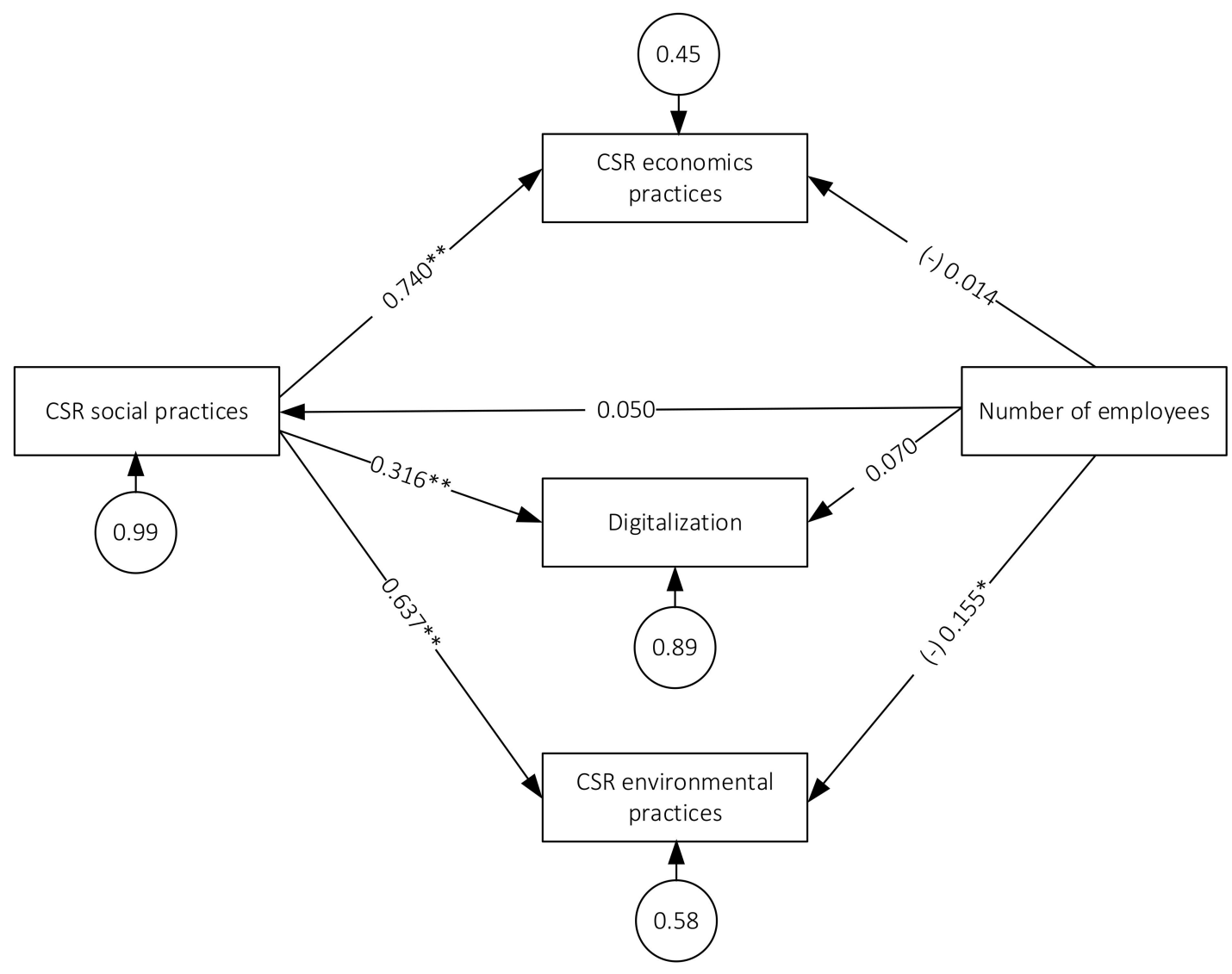

Figure 1. Results of SEM analysis: ${ }^{*} p<0.05,{ }^{* *} p<0.01$. 
The model shown in Figure 1. was obtained, for which $p$-value was 0.082, SRMR was 0.037, while GFI, AGFI, NFI, NNFI, CFI, were respectively: 0.975, 0.875, 0.959, 0.920, 0.976.

The results of the SEM analysis, presented in Figure 1 showed that the implementation of CSR social practices has an impact on both the implementation of economic (0.74) and environmental (0.637) CSR practices, what is more, the existence of an impact of social practices on the level of digitalization (0.316) was again demonstrated. Simultaneously, no statistically significant impact of the size of the organization on the level of digitization as well as economic and environmental practices was demonstrated. On the other hand, a slight negative influence of the size of the organization on environmental practices was shown.

\section{Discussion}

Although the environmental dimension is considered a pillar of CSR [128], the results of our study suggest a key role in social practices in influencing economic and environmental practices. This observation is consistent with the results of Bihari and Pradhan, suggesting that the social responsibility of organizations should be acknowledged [129]. Interestingly, the study did not identify the impact of economic practices on environmental practices and economic and environmental practices on social practices.

The results of our study are in line with the results of Currás-Pérez et al., who suggest that companies can influence social value only through social CSR initiatives because the social value is not influenced by the environmental and economic dimensions of CSR [70]. Similarly, the studies by Sila and Cek [130], and Šontaitè-Petkevičienè [131] indicate the impact of social practices on economic practices, suggesting that leaders should define ethical principles used as a basis for the development of economically sustainable business models. Currás-Pérez et al. explain the lack of impact of economic practices on the society by referring to the perception of economic initiatives as activities focused on profit compared to the better accepted and valued initiatives based on the social dimension of CSR [70]. Pan et al. show positive links between the social dimension of CSR and the environmental aspects of CSR, arguing that developing and engaging in social CSR practices undoubtedly increases the attractiveness of firms for talented employees. On the other hand, having such employees facilitates the implementation of environmental projects, e.g., eco-innovations. Pan et al. [132] maintain that firms with a more developed social dimension of CSR have employees with greater environmental awareness, which has an impact on environmental capabilities. Becker and Smith claim that taking care of the employees' motivation and engagement, inscribed in the social dimension of CSR, translates into the innovations needed for social responsibility-specifically regarding the environment [133].

The results of the study suggest the existence of an influence of social practices on digitalization, but do not confirm the influence of economic and environmental practices on digitalization. The results show that the focus on the needs of internal stakeholders, which translates into the formation of appropriate CSR competencies influencing the selection of digitalization tools [120], seems to have an impact on the level of digitalization. The results also suggest that it is important to have an open interaction with stakeholders, translating into sustainable development, thanks to which digitalization can strengthen the organization's ability to respond to phenomena in the environment [121].

The research does not make up a basis for inferring the impact of digitalization on any type of CSR practices, which, in the context of CSR research and digitalization [32,119,122-126] seems puzzling and undoubtedly requires in-depth analysis in future research.

Although the research results of $\mathrm{D}^{\prime}$ Amato and Falivena indicate that CSR initiatives may be ineffective in smaller and younger companies due to a lack of financial resources, experience, or reputation [134], in our research, we did not observe any relationships between size and any of the examined dimensions of CSR. The relationship between size and digitalization has also been unconfirmed. In addition, BarNir et al. suggest that company size is correlated with the availability and flexibility of resources and the 
susceptibility to competition in the industry, which in turn influences the digitalization of companies [135], and Salvi et al. [136] suggest that the size of the company influences the need to adopt digital solutions, but these relationships have not been confirmed in our research.

\section{Conclusions}

This article examines the relationships among CSR practices in the social, economic, and environmental dimensions and the digitalization in the energy sector enterprises. Empirical research confirms the influence of social practices on other CSR practices and on the level of digitalization and suggests that there is essentially no significant impact of the size of the enterprise on the level of digitalization, as well as on any of the analyzed types of CSR practices.

The results of this study have several potentially important implications. Firstly, they suggest that social practices are key practices in energy sector companies, affecting both economic and environmental practices, as well as digitalization. This observation allows us to conclude that managers of enterprises in the energy sector should pay particular attention to activities in this area. The emphasis should be put on cooperation with both external and internal stakeholders. Therefore, managers of energy sector companies should feel about raising public awareness of the activities undertaken in this sector by providing reliable information. Moreover, they should take care of the development of employees' competencies, their motivation to work, ensuring a high level of safety and a work-life balance. It is also justified to undertake activities for the local community, cooperate in social and charity projects and promote the development of the local community. Secondly, the lack of correlation between CSR practices and the size of enterprises that we have observed means that it is necessary to build managerial competencies in the area of interactions with internal and external stakeholders, regardless of the size. The negative link between the environmental CSR practices and the number of employees, which we observed in this study, may mean that large enterprises only declare activities for the benefit of the natural environment, but the declarations do not translate into reality. In fact, such firms just try to create an image of a pro-ecological enterprise, which is far from the assumptions of CSR.

This study has several limitations that can be considered as opportunities for future research. Firstly, the study is referred to an observation at a point in time and might not have captured and comprehensively explained the causal relationships. Future studies should be based on longitudinal data to carefully analyse the conclusions on the compounds that were tested in this study and should use the larger sample size to validate the reported empirical results. Secondly, the survey collected data using a self-report questionnaire which gave a cross-sectional picture but could omit important details. Therefore, in future studies, we recommend to conduct a more in-depth case study analysis. Thirdly, in the survey, we used a single respondent project, which allowed us to obtain data quickly, but could influence the subjectivity of the responses. Future research should use mixed methods and mixed data sources. Fourthly, the study does not discuss the results of energy sector companies in the area of CSR practices in comparison to companies from other sectors in Poland, neither companies from other jurisdictions, which may be interesting directions for further research.

Author Contributions: Conceptualization, A.C.-K., S.C., K.M. (Kamila Malewska), K.M. (Katarzyna Mierzejewska) and W.S.; methodology A.C.-K., S.C., K.M. (Kamila Malewska), K.M. (Katarzyna Mierzejewska) and W.S.; software, S.C., W.S.; validation, S.C., K.M. (Kamila Malewska) and W.S.; formal analysis, A.C.-K., S.C., K.M. (Kamila Malewska), K.M. (Katarzyna Mierzejewska) and W.S.; investigation, A.C.-K., K.M. (Katarzyna Mierzejewska); resources, A.C.-K., S.C., K.M. (Kamila Malewska), K.M. (Katarzyna Mierzejewska); data curation, A.C.-K., S.C., K.M. (Kamila Malewska), K.M. (Katarzyna Mierzejewska) and W.S.; writing-original draft preparation, A.C.-K., S.C., K.M. (Kamila Malewska), K.M. (Katarzyna Mierzejewska) and W.S.; writing-review and editing, A.C.-K., S.C., K.M. (Kamila Malewska), K.M. (Katarzyna Mierzejewska) and W.S.; visualization, A.C.-K., S.C., K.M. (Kamila Malewska), K.M. (Katarzyna Mierzejewska) and W.S.; supervision, S.C. and K.M. 
(Kamila Malewska); project administration, A.C.-K.; funding acquisition, A.C.-K. All authors have read and agreed to the published version of the manuscript.

Funding: The project financed within the Regional Initiative for Excellence programme of the Minister of Science and Higher Education of Poland, years 2019-2022, grant no. 004/RID/2018/19, financing 3,000,000 PLN.

Data Availability Statement: Publicly available datasets were analyzed in this study. This data can be found here: https:/ / osf.io/dvt2q/ (accessed on 20 September 2021).

Conflicts of Interest: The authors declare no conflict of interest. The funders had no role in the design of the study; in the collection, analyses, or interpretation of data; in the writing of the manuscript, or in the decision to publish the results.

\section{Appendix A. Research Questionnaire}

1. Please select one of the following statements related to the level of digitization in your company:

The management team is considering implementing a digital transformation strategy in the long term, but currently this is not a strategic goal of the company.

$\square \quad$ The management team organizes the business conditions which are essential for carrying out digital transformation and prepares employees to implement this change. Employees are aware of the need to digitize the company's operations.

$\square \quad$ The company uses modern ICT, processes are being automated, and there is cooperation with partners and research centres in order to improve the product manufacturing process.

$\square$ The company's employees use and create new technological solutions. Digitization occurs not only at the organizational level, but also at the individual level. It has become the foundation of the enterprise's organizational culture.

2. Corporate social responsibility (CSR).

\begin{tabular}{l}
\hline $\begin{array}{l}\text { Please rate the degree to which you agree or disagree with each of the following statements } \\
\text { Scale: } 1 \text { - strongly disagree, } 7 \text { - strongly agree }\end{array}$ \\
\hline (1) In the activities undertaken in our company: \\
\hline Environmental practices \\
\hline We assess the environmental impact of our activities \\
\hline We introduce energy and water saving activities \\
\hline We develop renewable energy sources \\
\hline We choose environmentally friendly suppliers \\
\hline We encourage our clients to care for the natural environment \\
\hline We implement waste and pollution control systems \\
\hline We strive to reduce the environmental impact of energy production/transmission \\
\hline We create activities that care for the natural environment \\
\hline Social practices \\
\hline We assess the impact of the activities undertaken on the local society \\
\hline We cooperate on social and charity projects \\
\hline We promote the development of the local community and heritage protection \\
\hline We strive to ensure the work and family life balance of employees \\
\hline We provide a high level of work safety \\
\hline We care about the high competencies and proper motivation of employees \\
\hline We interact openly with stakeholders \\
\hline
\end{tabular}




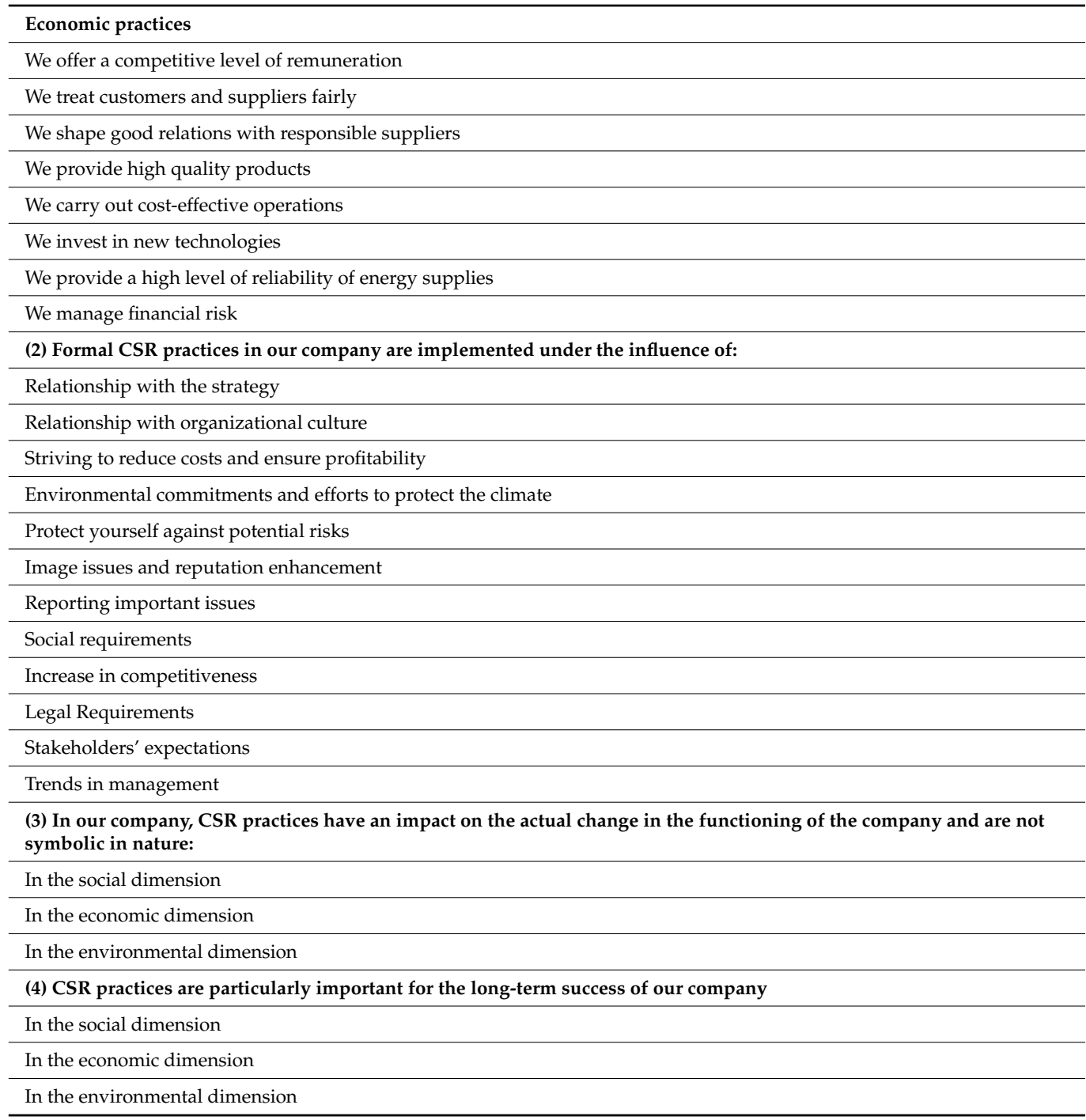

3. Demographic profiles of respondents to the questionnaire and the profile of the studied organisations

1. Please indicate the age of your company:

Less than 2 years

$2-5$ years

$6-10$ years

$11-25$ years

More than 25 years

2. Please indicate the number of employees in your company:

$10-49$

$50-249$

More than 250

\section{References}

1. Mitnick, B.M.; Windsor, D.; Wood, D.J. Csr: Undertheorized or essentially contested? Acad. Manag. Rev. 2021, 46, 623. [CrossRef]

2. Lulewicz-Sas, A. Corporate Social Responsibility in the Light of Management Science-Bibliometric Analysis. Procedia Eng. 2017, 182, 412-417. [CrossRef]

3. Sheehy, B. Defining CSR: Problems and Solutions. J. Bus. Ethics 2014, 131, 625-648. [CrossRef]

4. McWilliams, A.; Siegel, D. Corporate social responsibility and financial performance: Correlation or misspecification? Strateg. Manag. J. 2000, 21, 603-609. [CrossRef] 
5. Leveson, L.; Joiner, T.A. Exploring corporate social responsibility values of millennial job-seeking students. Educ. Train. 2014, 56, 21-34. [CrossRef]

6. Maqbool, S.; Zamir, N. Corporate social responsibility and institutional investors: The intervening effect of financial performance. J. Econ. Adm. Sci. 2021, 37, 238-252. [CrossRef]

7. Liczmańska-Kopcewicz, K.; Mizera, K.; Pypłacz, P. Corporate social responsibility and sustainable development for creating value for FMCG sector enterprises. Sustainability 2019, 11, 5808. [CrossRef]

8. Kolk, A.; van den Buuse, D. In search of viable business models for development: Sustainable energy in developing countries. Corp. Gov. 2012, 12, 551-567. [CrossRef]

9. Sánchez-Hernández, M.; Gallardo-Vazquez, D.; Dziwinski, P.; Barcik, A.; Sánchez-Hernández, M. Sustainable Development at Enterprise Level: CSR in Spain and Poland. Available online: https://web.a.ebscohost.com/ehost/detail/detail?vid=0\&sid=14e1 8fb5-c3cc-4f9e-b4f3-ae7f85c3d877\%40sdc-v-sessmgr02\&bdata=Jmxhbmc9cGwmc210ZT1laG9zdC1saXZ1\#AN=80919153\&db= obo (accessed on 20 September 2021).

10. Abdelhalim, K.; Eldin, A.G. Can CSR help achieve sustainable development? Applying a new assessment model to CSR cases from Egypt. Int. J. Sociol. Soc. Policy 2019, 39, 773-795. [CrossRef]

11. Moyeen, A.; West, B. Promoting CSR to foster sustainable development: Attitudes and perceptions of managers in a developing country. Asia-Pac. J. Bus. Adm. 2014, 6, 97-115. [CrossRef]

12. Lloyd, R. The Impact of CSR Efforts on Firm Performance in the Energy Sector. Ph.D. Thesis, George Fox University, Newberg, OR, USA, 2017.

13. Stjepcevic, J.; Siksnelyte, I. Corporate Social Responsibility in Energy Sector. Transform. Bus. Econ. 2017, 16, 21-33.

14. Arena, M.; Azzone, G.; Mapelli, F. What drives the evolution of Corporate Social Responsibility strategies? An institutional logics perspective. J. Clean. Prod. 2018, 171, 345-355. [CrossRef]

15. Hede Skagerlind, H.; Westman, M.; Berglund, H. Corporate Social Responsibility through Cross-sector Partnerships: Implications for Civil Society, the State, and the Corporate Sector in India. Bus. Soc. Rev. 2015, 120, 245-275. [CrossRef]

16. Mezher, T.; Tabbara, S.; Al-Hosany, N. An overview of CSR in the renewable energy sector: Examples from the Masdar Initiative in Abu Dhabi. Manag. Environ. Qual. Int. J. 2010, 21, 744-760. [CrossRef]

17. Zhao, G.; Irfan Ahmed, R.; Ahmad, N.; Yan, C.; Usmani, M.S. Prioritizing critical success factors for sustainable energy sector in China: A DEMATEL approach. Energy Strateg. Rev. 2021, 35, 2-13. [CrossRef]

18. Latapí Agudelo, M.A.; Johannsdottir, L.; Davidsdottir, B. Drivers that motivate energy companies to be responsible. A systematic literature review of Corporate Social Responsibility in the energy sector. J. Clean. Prod. 2020, 247, 119094. [CrossRef]

19. Solomon, S.; Qin, D.; Manning, M.; Chen, Z.; Marquis, M.; Averyt, K.B.; Tingor, M.; Miller, H.L. Climate Change 2007: The Physical Science Basis. Contribution of Working Group I to the Third Assessment Report of the Intergovernmental Panel on Climate Change. In Climate Change 2021: The Physical Science Basis. Contribution of Working Group I to the Sixth Assessment Report of the Intergovernmental Panel on Climate Change; Masson-Delmotte, V., Zhai, P., Pirani, A., Connors, S.L., Péan, C., Berger, S., Caud, N., Chen, Y., Goldfarb, L., Gomis, M.I., et al., Eds.; IPCC: Geneva, Switzerland, 2001; p. 48.

20. Streimikiene, D.; Simanaviciene, Z.; Kovaliov, R. Corporate social responsibility for implementation of sustainable energy development in Baltic States. Renew. Sustain. Energy Rev. 2009, 13, 813-824. [CrossRef]

21. Lu, J.; Liang, M.; Zhang, C.; Rong, D.; Guan, H.; Mazeikaite, K.; Streimikis, J. Assessment of corporate social responsibility by addressing sustainable development goals. Corp. Soc. Responsib. Environ. Manag. 2021, 28, 686-703. [CrossRef]

22. Paliwoda-Matiolanska, A.; Smolak-Lozano, E.; Nakayama, A. Corporate image or social engagement: Twitter discourse on corporate social responsibility (CSR) in public relations strategies in the energy sector. Prof. Inf. 2020, 29, 18. [CrossRef]

23. Stuss, M.M.; Makieła, Z.J.; Herdan, A.; Kuźniarska, G. Energy Companies Obligation. Energies 2021, 14, 3815. [CrossRef]

24. Bashtovaya, V. CSR reporting in the United States and Russia. Soc. Responsib. J. 2014, 10, 68-84. [CrossRef]

25. Karaman, A.S.; Orazalin, N.; Uyar, A.; Shahbaz, M. CSR achievement, reporting, and assurance in the energy sector: Does economic development matter? Energy Policy 2020, 149, 112007. [CrossRef]

26. Benyaminova, A.; Mathews, M.; Langley, P.; Rieple, A. The impact of changes in stakeholder salience on corporate social responsibility activities in Russian energy firms: A contribution to the divergence/convergence debate. Corp. Soc. Responsib. Environ. Manag. 2019, 26, 1222-1234. [CrossRef]

27. Hengst, I.-A.; Muethel, M. Paradoxes and Dilemmas in Corporate Social Responsibility Strategy Execution. Acad. Manag. Proc. 2015, 2015, 14575. [CrossRef]

28. Sharma, A. Key drivers endorsing CSR: A transition from economic to holistic approach. Asian J. Bus. Ethics 2016, 5, 165-184. [CrossRef]

29. Abaeian, V.; Khong, K.W.; Kyid Yeoh, K.; McCabe, S. Motivations of undertaking CSR initiatives by independent hotels: A holistic approach. Int. J. Contemp. Hosp. Manag. 2019, 31, 2468-2487. [CrossRef]

30. Digitalization E Energy; IEA: Paris, France, 2017.

31. Turker, D. Measuring corporate social responsibility: A scale development study. J. Bus. Ethics 2009, 85, 411-427. [CrossRef]

32. Brenner, B.; Hartl, B. The perceived relationship between digitalization and ecological, economic, and social sustainability. $J$. Clean. Prod. 2021, 315, 128128. [CrossRef]

33. Costa, R.; Menichini, T. A multidimensional approach for CSR assessment: The importance of the stakeholder perception. Expert Syst. Appl. 2013, 40, 150-161. [CrossRef] 
34. Torugsa, N.A.; O'Donohue, W.; Hecker, R. Proactive CSR: An Empirical Analysis of the Role of its Economic, Social and Environmental Dimensions on the Association between Capabilities and Performance. J. Bus. Ethics 2013, 115, 383-402. [CrossRef]

35. Cyfert, S.; Glabiszewski, W.; Zastempowski, M. Impact of management tools supporting industry 4.0 on the importance of csr during covid-19. generation z. Energies 2021, 14, 1642. [CrossRef]

36. Delautre Bruno, G.; Abriata, D. Corporate Social Responsibility: Exploring Determinants and Complementarities; International Labour Office: Geneva, Switzerland, 2018.

37. Low, M.P. Corporate Social Responsibility and the Evolution of Internal Corporate Social Responsibility in 21st Century. Asian J. Soc. Sci. Manag. Stud. 2016, 3, 56-74. [CrossRef]

38. Jia, Y.; Yan, J.; Liu, T.; Huang, J. How does internal and external CSR affect employees' work engagement? Exploring multiple mediation mechanisms and boundary conditions. Int. J. Environ. Res. Public Health 2019, 16, 2476. [CrossRef]

39. Papasolomou, I. The Practice of Internal Corporate Social Responsibility in SMEs in Cyprus. In Corporate Social Responsibility in Times of Crisis; Idowu, S.O., Vertigans, S., Burlea, A.S., Eds.; Springer: Berlin/Heidelberg, Germany, 2017; pp. 93-109. ISBN 9783319528397.

40. Hiswåls, A.S.; Hamrin, C.W.; Vidman, A.; Macassa, G. Corporate social responsibility and external stakeholders' health and wellbeing: A viewpoint. J. Public Health Res. 2020, 9, 27-30. [CrossRef]

41. Odongo, G.; Masinde, J.M.; Masese, E.R.; Abuya, W.O. The Impact of CSR on Corporate-Society Relations. J. Adv. Res. Sociol. 2019, 1, 9-15.

42. Husted, B.W.; De Jesus Salazar, J. Taking friedman seriously: Maximizing profits and social performance. J. Manag. Stud. 2006, 43, 75-91. [CrossRef]

43. Husted, B.W.; Allen, D.B.; Kock, N. Value Creation Through Social Strategy. Bus. Soc. 2015, 54, 147-186. [CrossRef]

44. Husted, B.W.; Allen, D.B. Strategic Corporate Social Responsibility and Value Creation among Large Firms. Lessons from the Spanish Experience. Long Range Plann. 2007, 40, 594-610. [CrossRef]

45. Bacinello, E.; Tontini, G.; Alberton, A. Influence of corporate social responsibility on sustainable practices of small and mediumsized enterprises: Implications on business performance. Corp. Soc. Responsib. Environ. Manag. 2021, 28, 776-785. [CrossRef]

46. McWilliams, A.; Siegel, D.S.; Wright, P.M. Corporate social responsibility: Strategic implications. J. Manag. Stud. 2006, 43, 1-18. [CrossRef]

47. Ite, U.E. Multinationals and corporate social responsibility in developing countries: A case study of Nigeria. Corp. Soc. Responsib. Environ. Manag. 2004, 11, 1-11. [CrossRef]

48. Giemza, M. Przyczyny oraz skutki implementacji zasad społecznej odpowiedzialności biznesu do zarządzania firmą. Ekon. Społeczna 2019, 2, 72-81. [CrossRef]

49. Potočan, V.; Mulej, M.; Nedelko, Z. Society 5.0: Balancing of Industry 4.0, economic advancement and social problems. Kybernetes 2021, 50, 794-811. [CrossRef]

50. Kuzior, A.; Ober, J.; Karwot, J. Stakeholder expectation of corporate social responsibility practices: A case study of pwik rybnik, Poland. Energies 2021, 14, 3337. [CrossRef]

51. Vavra, J.; Bednarikova, M.; Munzarova, S.; Tetrevova, L. Relevant CSR activities for strengthening social profile of metallurgical company. In Proceedings of the METAL 2016 - 25th Anniversary International Conference on Metallurgy and Materials, Brno, Czech Republic, 25-27 May 2016; pp. 2061-2068.

52. Amor-Esteban, V.; Galindo-Villardón, M.P.; García-Sánchez, I.M.; David, F. An extension of the industrial corporate social responsibility practices index: New information for stakeholder engagement under a multivariate approach. Corp. Soc. Responsib. Environ. Manag. 2019, 26, 127-140. [CrossRef]

53. Grishnova, O.; Bereziuk, K.; Bilan, Y. Evaluation of the level of corporate social responsibility of Ukrainian nuclear energy producers. Manag. Mark. 2021, 16, 152-166. [CrossRef]

54. Gulema, T.F.; Roba, Y.T. Internal and external determinants of corporate social responsibility practices in multinational enterprise subsidiaries in developing countries: Evidence from Ethiopia. Futur. Bus. J. 2021, 7, 7. [CrossRef]

55. Marinina, O. Analysis of trends and performance of CSR mining companies. IOP Conf. Ser. Earth Environ. Sci. 2019, 302, 012120. [CrossRef]

56. Zaighum, S.A.K.; Ahmad, G.; Parveen, K. Workers' Perceptions of CSR Practices: Analysis of a Textile Organization in Pakistan. Glob. Bus. Manag. Res. Int. J. 2021, 13, 43-57.

57. Gadenne, D.L.; Kennedy, J.; McKeiver, C. An empirical study of environmental awareness and practices in SMEs. J. Bus. Ethics 2009, 84, 45-63. [CrossRef]

58. Morales-Raya, M.; Martín-Tapia, I.; Ortiz-de-mandojana, N. To be or to seem: The role of environmental practices in corporate environmental reputation. Organ. Environ. 2019, 32, 309-330. [CrossRef]

59. Thorlakson, T.; Hainmueller, J.; Lambin, E.F. Improving environmental practices in agricultural supply chains: The role of company-led standards. Glob. Environ. Chang. 2018, 48, 32-42. [CrossRef]

60. Mijatovic, I.; Maricic, M.; Horvat, A. The factors affecting the environmental practices of companies: The case of Serbia. Sustainability 2019, 11, 5960. [CrossRef]

61. Uhlaner, L.M.; Berent-Braun, M.M.; Jeurissen, R.J.M.; de Wit, G. Beyond Size: Predicting Engagement in Environmental Management Practices of Dutch SMEs. J. Bus. Ethics 2012, 109, 411-429. [CrossRef] 
62. Hoogendoorn, B.; Guerra, D.; van der Zwan, P. What drives environmental practices of SMEs? Small Bus. Econ. 2015, 44, 759-781. [CrossRef]

63. Tate, W.L.; Dooley, K.J.; Ellram, L.M. Transaction cost and institutional drivers of supplier adoption of environmental practices. J. Bus. Logist. 2011, 32, 6-16. [CrossRef]

64. Babiak, K.; Trendafilova, S. CSR and environmental responsibility: Motives and pressures to adopt green management practices. Corp. Soc. Responsib. Environ. Manag. 2011, 18, 11-24. [CrossRef]

65. Ahmed, D.A.H.; Eliwa, Y.; Power, D.M. The impact of corporate social and environmental practices on the cost of equity capital: UK evidence. Int. J. Account. Inf. Manag. 2019, 27, 425-441. [CrossRef]

66. Seles, B.M.R.P.; Lopes de Sousa Jabbour, A.B.; Jabbour, C.J.C.; Latan, H.; Roubaud, D. Do Environmental Practices Improve Business Performance Even in an Economic Crisis? Extending the Win-Win Perspective. Ecol. Econ. 2019, 163, 189-204. [CrossRef]

67. Graham, S.; Potter, A. Environmental operations management and its links with proactivity and performance: A study of the UK food industry. Int. J. Prod. Econ. 2015, 170, 146-159. [CrossRef]

68. Chen, C.M.; Ho, H. Who pays you to be green? How customers' environmental practices affect the sales benefits of suppliers' environmental practices. J. Oper. Manag. 2019, 65, 333-352. [CrossRef]

69. Garay, L.; Font, X. Doing good to do well? Corporate social responsibility reasons, practices and impacts in small and medium accommodation enterprises. Int. J. Hosp. Manag. 2012, 31, 329-337. [CrossRef]

70. Currás-Pérez, R.; Dolz-Dolz, C.; Miquel-Romero, M.J.; Sánchez-García, I. How social, environmental, and economic CSR affects consumer-perceived value: Does perceived consumer effectiveness make a difference? Corp. Soc. Responsib. Environ. Manag. 2018, 25, 733-747. [CrossRef]

71. Carroll, A.B. The pyramid of corporate social responsibility: Toward the moral management of organizational stakeholders. Bus. Horiz. 1991, 34, 39-48. [CrossRef]

72. Chen McCain, S.L.; Lolli, J.C.; Liu, E.; Jen, E. The relationship between casino corporate social responsibility and casino customer loyalty. Tour. Econ. 2019, 25, 569-592. [CrossRef]

73. Zhao, L.; Lee, J.; Moon, S. Employee response to CSR in China: The moderating effect of collectivism. Pers. Rev. 2019, 48, 839-863. [CrossRef]

74. Carroll, A.B. Corporate social responsibility: Evolution of a definitional construct. Bus. Soc. 1999, 38, 268-295. [CrossRef]

75. Mahmood, A.; Bashir, J. How does corporate social responsibility transform brand reputation into brand equity? Economic and noneconomic perspectives of CSR. Int. J. Eng. Bus. Manag. 2020, 12, 1-13. [CrossRef]

76. Singh, S.; Mittal, S. Analysis of drivers of CSR practices' implementation among family firms in India: A stakeholder's perspective. Int. J. Organ. Anal. 2019, 27, 947-971. [CrossRef]

77. Wut, T.M.; Xu, B.; Wong, H.S.M. A 15-year Review of “Corporate Social Responsibility Practices" Research in the Hospitality and Tourism Industry. J. Qual. Assur. Hosp. Tour. 2021. [CrossRef]

78. González-Rodríguez, M.R.; Díaz-Fernández, M.C.; Simonetti, B. The social, economic and environmental dimensions of corporate social responsibility: The role played by consumers and potential entrepreneurs. Int. Bus. Rev. 2015, 24, 836-848. [CrossRef]

79. Hsieh, S.C.; Chiu, H.C.; Hsieh, Y.H.; Ho, P.S.; Chen, L.C.; Chang, W.C. The Perceptions and Expectations Toward the Social Responsibility of Hospitals and Organizational Commitment of Nursing Staff. J. Nurs. Res. 2016, 24, 249-261. [CrossRef] [PubMed]

80. Pereira, T.; Gadotti dos Anjos, S.J. Corporate Social Responsibility as Resource for Tourism Development Support. Tour. Plan. Dev. 2021. Online ahead of print. [CrossRef]

81. De Los Salmones, M.D.M.G.; Crespo, A.H.; Del Bosque, I.R. Influence of corporate social responsibility on loyalty and valuation of services. J. Bus. Ethics 2005, 61, 369-385. [CrossRef]

82. Lu, J.; Ren, L.; Qiao, J.; Yao, S.; Strielkowski, W.; Streimikis, J. Corporate social responsibility and corruption: Implications for the sustainable energy sector. Sustainability 2019, 11, 4128. [CrossRef]

83. Stocker, F.; de Arruda, M.P.; de Mascena, K.M.C.; Boaventura, J.M.G. Stakeholder engagement in sustainability reporting: A classification model. Corp. Soc. Responsib. Environ. Manag. 2020, 27, 2071-2080. [CrossRef]

84. An, J.; Mikhaylov, A.; Richter, U.H. Trade war effects: Evidence from sectors of energy and resources in Africa. Heliyon 2020, 6, e05693. [CrossRef]

85. Garstecki, D.; Kowalczyk, M.; Kwiecińska, K. CSR practices in Polish and Spanish stock listed companies: A comparative analysis. Sustainability 2019, 11, 1054. [CrossRef]

86. Mory, L.; Wirtz, B.W.; Göttel, V. Factors of internal corporate social responsibility and the effect on organizational commitment. Int. J. Hum. Resour. Manag. 2016, 27, 1393-1425. [CrossRef]

87. Syrjälä, J.; Takala, T. Before and after: Employees' views on corporate social responsibility: Energy-sector stakeholders in Nordic post-merger integration. Soc. Responsib. J. 2009, 5, 265-279. [CrossRef]

88. de Vries, G.; Terwel, B.W.; Ellemers, N.; Daamen, D.D.L. Sustainability or profitability? How communicated motives for environmental policy affect public perceptions of corporate greenwashing. Corp. Soc. Responsib. Environ. Manag. 2015, 22, 142-154. [CrossRef]

89. Ekatah, I.; Samy, M.; Bampton, R.; Halabi, A. The relationship between corporate social responsibility and profitability: The case of royal dutch shell plc. Corp. Reput. Rev. 2011, 14, 249-261. [CrossRef] 
90. Pätäri, S.; Arminen, H.; Tuppura, A.; Jantunen, A. Competitive and responsible? the relationship between corporate social and financial performance in the energy sector. Renew. Sustain. Energy Rev. 2014, 37, 142-154. [CrossRef]

91. Lee, S.-P. Environmental responsibility, CEO power and financial performance in the energy sector. Rev. Manag. Sci. 2021, 15, 2407-2426. [CrossRef]

92. Pätäri, S.; Jantunen, A.; Kyläheiko, K.; Sandström, J. Does Sustainable Development Foster Value Creation? Empirical Evidence from the Global Energy Industry. Corp. Soc. Responsib. Environ. Manag. 2012, 19, 317-326. [CrossRef]

93. Kerckhoffs, T.; Wilde-Ramsing, J. European Works Councils and Corporate Social Responsibility in the European Energy Sector; EPSU: Amsterdam, The Netherlands, 2010.

94. Siano, A.; Conte, F.; Amabile, S.; Vollero, A.; Piciocchi, P. Communicating Sustainability: An Operational Model for Evaluating sustainability Communicating Sustainability: An Operational Model for Evaluating Corporate Websites. Sustainability 2016, 8 , 950. [CrossRef]

95. Kuo, L. Disclosure of Corporate Social Responsibility and Environmental Management: Evidence from China. Corp. Soc. Responsib. Environ. Manag. 2011, 19, 273-287. [CrossRef]

96. Lu, J.; Ren, L.; Yao, S.; Qiao, J.; Strielkowski, W.; Streimikis, J. Comparative review of corporate social responsibility of energy utilities and sustainable energy development trends in the Baltic states. Energies 2019, 12, 3417. [CrossRef]

97. Ionescu, B.-S.; Feleaga, L.; Dumitrascu, L.-M. Does the shareholder salience influence the corporate social responsibility of entities from energy sector? In Proceedings of the 14th International Conference on Business Excellence 2020, Bucharest, Romania, 27 May 2020; pp. 225-235.

98. Kittner, N.; Lill, F.; Kammen, D.M. Energy storage deployment and innovation for the clean energy transition. Nat. Energy 2017, 2, 17125. [CrossRef]

99. Tagliapietra, S.; Zachmann, G.; Edenhofer, O.; Glachant, J.M.; Linares, P.; Loeschel, A. The European union energy transition: Key priorities for the next five years. Energy Policy 2019, 132, 950-954. [CrossRef]

100. Mostue, L.; Moengen, T. Digitalisation of the Energy Sector Recommendations for Research and Innovation Background; TANK Design: Oslo, Norway, 2021; ISBN 978-82-12-03850-9.

101. Weigel, P.; Fischedick, M. Review and categorization of digital applications in the energy sector. Appl. Sci. 2019, 9, 5350. [CrossRef]

102. Goldbach, K.; Rotaru, A.M.; Reichert, S.; Stiff, G.; Gölz, S. Which digital energy services improve energy efficiency? A multi-criteria investigation with European experts. Energy Policy 2018, 115, 239-248. [CrossRef]

103. Chhina, S.; Chadhar, M.; Vatanasakdakul, S.; Chetty, M. Challenges and opportunities for Blockchain Technology adoption: A systematic review. In Proceedings of the Australasian Conference on Information Systems, Perth, Australia, 9-11 August 2019; pp. 761-770.

104. Alekseev, A.N.; Lobova, S.V.; Bogoviz, A.V.; Ragulina, Y.V. Digitalization of the Russian energy sector: State-of-the-art and potential for future research. Int. J. Energy Econ. Policy 2019, 9, 274-280. [CrossRef]

105. Burda, Y.D.; Volkova, I.O.; Gavrikova, E.V.; Kosygina, A.V. Digitalization and ways for the development of the electric energy industry with the participation of consumers: New challenges for shaping the investment climate. J. Sib. Fed. Univ. Humanit. Soc. Sci. 2019, 12, 545-564. [CrossRef]

106. Gribanov, Y.; Shatrov, A. Modular digitalization of the energy sector. IOP Conf. Ser. Mater. Sci. Eng. 2019, 497, 012072. [CrossRef]

107. Konstantinos, P. Digitalization of Energy Sector; European Comission: Brussels, Belgium, 2019.

108. Ghobakhloo, M.; Fathi, M. Industry 4.0 and opportunities for energy sustainability. J. Clean. Prod. 2021, 295, 126427. [CrossRef]

109. Akberdina, V.; Osmonova, A. Digital transformation of energy sector companies. E3S Web Conf. 2021, 250, 06001. [CrossRef]

110. Adenuga, O.T.; Mpofu, K.; Boitumelo, R.I. Energy efficiency analysis modelling system for manufacturing in the context of industry 4.0. Procedia CIRP 2019, 80, 735-740. [CrossRef]

111. Ziyadin, S.; Suieubayeva, S.; Utegenova, A. Digital Transformation in Business; Springer International Publishing: Berlin/Heidelberg, Germany, 2020; Volume 84, ISBN 9783030270155.

112. Brown, M.; Woodhouse, S.; Sioshansi, F. Digitalization of energy. In Consumer Prosumer, Prosumager How Service Innovations Will Disrupt Utility Business Model; Academic Press: Cambridge, MA, USA, 2019; pp. 3-25. [CrossRef]

113. Dang, D.; Vartiainen, T. Changing Patterns in the Process of Digital Transformation Initiative in Established Firms: The Case of an Energy Sector Company; Association for Information Systems (AIS): Atlanta, GA, USA, 2020.

114. Industry 4.0. in the Energy Sector-BiznesAlert EN. Available online: https://biznesalert.com/industry-4-0-in-the-energysector / (accessed on 18 October 2021).

115. Annunziata, M.; Bell, G.; Buch, R.; Patel, S.S. Powering the Future-Leading the Digital Transformation of the Power Industry; General Electric Company: Boston, MA, USA, 2016.

116. Loock, M. Unlocking the value of digitalization for the European energy transition: A typology of innovative business models. Energy Res. Soc. Sci. 2020, 69, 101740. [CrossRef]

117. Forcadell, F.J.; Aracil, E.; Úbeda, F. The Impact of Corporate Sustainability and Digitalization on International Banks' Performance. Glob. Policy 2020, 11, 18-27. [CrossRef]

118. Del Río Castro, G.; González Fernández, M.C.; Uruburu Colsa, Á. Unleashing the convergence amid digitalization and sustainability towards pursuing the Sustainable Development Goals (SDGs): A holistic review. J. Clean. Prod. 2021, $280,122204$. [CrossRef] 
119. Seele, P.; Lock, I. The game-changing potential of digitalization for sustainability: Possibilities, perils, and pathways. Sustain. Sci. 2017, 12, 183-185. [CrossRef]

120. Latapí Agudelo, M.A.; Jóhannsdóttir, L.; Davídsdóttir, B. A literature review of the history and evolution of corporate social responsibility. Int. J. Corp. Soc. Responsib. 2019, 4, 1-23. [CrossRef]

121. van der Velden, M. Maja Digitalisation and the UN Sustainable Development Goals: What role for design. Interact. Des. Archit. J. 2018, 37, 160-174.

122. Belyaeva, Z.; Lopatkova, Y. The Impact of Digitalization and Sustainable Development Goals in SMEs' Strategy: A Multi-Country European Study; Springer: Berlin/Heidelberg, Germany, 2020; pp. 15-38. [CrossRef]

123. Bhutani, S.; Paliwal, Y. Digitalization: A Step Towards Sustainable Development. Int. J. Sustain. Dev. 2015, 8, 11-24.

124. Esposito, P.; Ricci, P. Cultural organizations, digital Corporate Social Responsibility and stakeholder engagement in virtual museums: A multiple case study. How digitization is influencing the attitude toward CSR. Corp. Soc. Responsib. Environ. Manag. 2021, 28, 953-964. [CrossRef]

125. Niehoff, S.; Beier, G. Industrie 4.0 and a sustainable development: A short study on the perception and expectations of experts in Germany. Int. J. Innov. Sustain. Dev. 2018, 12, 360. [CrossRef]

126. Arnold, M.G.; Fischer, A. Digitization and Sustainability; ACCB Publishing: North Shields, UK, 2019; pp. 1-28. [CrossRef]

127. Greiner, L.E. Evolution and revolution as organizations grow. 1972. Harv. Bus. Rev. 1998, 76, 55-64. [CrossRef]

128. Williamson, D.; Lynch-Wood, G.; Ramsay, J. Drivers of environmental behaviour in manufacturing SMEs and the implications for CSR. J. Bus. Ethics 2006, 67, 317-330. [CrossRef]

129. Bihari, S.C.; Pradhan, S. CSR and Performance: The Story of Banks in India. J. Transnatl. Manag. 2011, 16, 20-35. [CrossRef]

130. Sila, I.; Cek, K. The Impact of Environmental, Social and Governance Dimensions of Corporate Social Responsibility on Economic Performance: Australian Evidence. Procedia Comput. Sci. 2017, 120, 797-804. [CrossRef]

131. Šontaitè-Petkevičienė, M. CSR Reasons, Practices and Impact to Corporate Reputation. Procedia Soc. Behav. Sci. 2015, 213, 503-508. [CrossRef]

132. Pan, X.; Sinha, P.; Chen, X. Corporate social responsibility and eco-innovation: The triple bottom line perspective. Corp. Soc. Responsib. Environ. Manag. 2021, 28, 214-228. [CrossRef]

133. Becker, W.S.; Smith, R.J. Social and Environmental Responsibility, Sustainability, and Human Resource Practices. SSRN Electron. J. 2012. [CrossRef]

134. D'Amato, A.; Falivena, C. Corporate social responsibility and firm value: Do firm size and age matter? Empirical evidence from European listed companies. Corp. Soc. Responsib. Environ. Manag. 2020, 27, 909-924. [CrossRef]

135. BarNir, A.; Gallaugher, J.M.; Auger, P. Business process digitization, strategy, and the impact of firm age and size: The case of the magazine publishing industry. J. Bus. Ventur. 2003, 6, 789-814. [CrossRef]

136. Salvi, A.; Vitolla, F.; Rubino, M.; Giakoumelou, A.; Raimo, N. Online information on digitalisation processes and its impact on firm value. J. Bus. Res. 2021, 124, 437-444. [CrossRef] 